\title{
ANALYSIS OF THE ROLE OF OFFICERS IN IMPORT MALARIA CONTROL IN PANDEAN PUSKESMAS DISTRICT TRENGGALEK
}

\author{
Rike Dwi Anggraini ${ }^{1}$, Azizah ${ }^{1}$ \\ ${ }^{1}$ Department of Environmental Health, \\ Faculty of Public Health, Airlangga University, Surabaya, Indonesia \\ Correspondence Address: Rike Dwi Anggraini \\ Email : rikedwi25@gmail.com
}

\begin{abstract}
ABSTRACK
Malaria remains a health problem in the world. In Indonesia, malaria is one of the causes of the outbreak in the province of East Java. Pandean is a public health center thatcounted for large numbers in cases of malaria in Trenggalek. Although Pandean public health center has conducted treatment of imported malaria, the cases are still high. The purpose of this research is to analyze the role of officers in the implementation of discovery and treatment program of imported malaria, including the availability of human resources, training, knowledge and understanding of the auth. This research is a descriptive observational research. Respondents in the study were 8 people, including Program Managers Of Malaria, 2 Microscopic and 5 JMD in Pandean public health center area. Data retrieval was implemented with interviews against the respondents and secondary data searches in Pandean. The results showed they have the good availability of human resources, but there is no the head of JMD yet. Officer of the discovery and treatment of malaria have had a good knowledge, they have received training, and also have a good working understanding of auth, malaria program officer Role has been good, but they need to keep the improvements including recruitment of the head of JMD to avoid duplicate tasks so that the control of imported malaria can run optimally.
\end{abstract}

Keywords: Malaria import control, The role of officers, Public Health Center

\begin{abstract}
ABSTRAK
Malaria masih menjadi masalah kesehatan di dunia. Di Indonesia, malaria merupakan salah satu penyebab KLB di Provinsi Jawa Timur. Puskesmas Pandean merupakan Puskesmas yang menyumbang angka besar dalam kasus malaria di Kabupaten Trenggalek. Meskipun Puskesmas Pandean telah melakukan penemuan dan pengobatan malaria impor, kasus malaria impor masih tinggi. Tujuan dari penelitian ini adalah menganalisis peran petugas dalam pelaksanaan program penemuan dan pengobatan malaria impor, meliputi ketersediaan Sumber Daya Manusia, pengetahuan, pelatihan dan pemahaman tupoksi. Penelitian ini merupakan penelitian observasional deskriptif. Terdapat 8 responden dalam penelitian ini yaitu pengelola program malaria, 2 orang Mikroskopis, dan 5 orang JMD wilayah Puskesmas Pandean. Pengambilan data dilaksanakan dengan wawancara terhadap responden dan penelusuran data sekunder di Puskesmas Pandean. Hasil penelitian menunjukkan bahwa dalam faktor petugas program malaria telah memiliki ketersediaan SDM yang baik, namun tidak terdapat tenaga Kepala $J M D$. Petugas pengendalian malaria telah memiliki pengetahuan yang baik, telah mendapatkan pelatihan, dan juga memiliki pemahaman tugas pokok dan fungsi kerja yang baik. Peran petugas program malaria telah baik, namun perlu adanya perbaikan diantaranya merekrut tenaga Kepala JMD agar tidak terjadi tugas rangkap sehingga pengendalian malaria impor dapat berjalan optimal.
\end{abstract}

Kata Kunci: Pengendalian malaria impor, peran petugas, Puskesmas Pandean

\section{INTRODUCTION}

World Malaria Report 2015 mentions that Malaria has invaded 106 countries in the world (Ministry of Health, 2016). The WHO estimated the incidence of malaria in 2015 as many as 212 million cases worldwide. The region that ranked the first occurrence of malaria is Africa
(90\%), then the second is South East Asia $(7 \%)$, and the last stage is the Eastern Mediterranean region (2\%). Incidence of this malaria decreased compared with the year 2000 about $22 \%$ and decreased by $14 \%$ since 2010 (WHO, 2016). The cause of malaria in various regions of the world is estimated $4 \%$ is the Plasmodium vivax which spreads in various countries in the 
world including India, Ethiopia, Pakistan, Indonesia and other countries 2010 (WHO, 2016).

Malaria is one of the problems of public health that can cause death especially in the high risk groups of infants, toddlers, and pregnant mothers. In addition malaria can directly cause anemia and can decrease the productivity of the work (Ministry of Health, 2011). According to Indonesian government official data, in 2007, it is said that 396 of the 495 districts in Indonesia are endemic malaria and $45 \%$ of Indonesians live in areas at risk of contracting malaria. The incidence of malaria of $2.9 \%$ (2007) fell to $1.9 \%$ (2013) and the mortality rate due to malaria also dropped from $0.92 \%$ (2005) to $0.56 \%$ (2007). But in the year 2011 there was a malaria in nine districts/cities (Ministry of Health, 2010), (Ministry of Health 2011).

Malaria cases in Indonesia are increasing annually. In 2015 cases of positive malaria as much as 217,025 and malaria sufferers who have received the treatment ACT 90\% of the case (Ministry of Health, 2016). The malaria that occurs in East Java province is dominated by cases of import Malaria and a small portion of Indigenous Malaria. The high case of import malaria is influenced by population mobility from and to endemic malaria areas outside of the high Java island. The trend of malaria sufferers reaches the highest in January, while rising trends occur in May, July and August. The upward trend occurred in July along with the mobility of residents to return to the village of Eid al-Fitr from endemic malaria area. High Malaria imports that are not found and treated are very risky to transmit Malaria in the receptive area. Malaria receptive areas in East Java spread across the south coast of East Java and around the mountains of Wilis and in the archipelago area of Sumenep (Ministry of Health, 2014).

Malaria is one of the causes of KLB in East Java province. In 2014, most of East Java province received a malaria elimination certificate, 38 district/city has not received malaria elimination certificate, such as Pacitan Regency, Trenggalek Regency, Madiun Regency and Banyuwangi.

The effort to eradicate malaria is one of the common goals that must be achieved until 2015 in the global commitment to the millennial Development Goals (MDGs). The attempted eradication of malaria did not reach the desired target and then continued through Sustainable Development Global (SDGs). In SDGs, malaria eradication efforts are on the third goal of ensuring a healthy life and seeking welfare for all people with a specific goal of ending an AIDS epidemic, tuberculosis, malaria, neglected-tropical disease Until the year 2030. Malaria control in East Java is carried out thoroughly by controlling the vector density, finding as early as possible Malaria sufferers, treating sufferers, improving human resources in medical personnel, laboratory personnel, managers (JMD), and cross-sector coordination.

Trenggalek Regency is one of the endemic areas of malaria in East Java province which ranks first in the case of malaria in 2014-2015. The trend of malaria cases in Trenggalek district from 2012-2015 decreased but is still a district with the highest cases of malaria in East Java province. In the case of malaria in Trenggalek District, the Puskesmas that contributes the big number is Pandean Puskesmas.

Cases of malaria in Trenggalek District especially the working area of Pandean Puskesmas is the majority case of imported malaria. Malaria imports is one of the positive malaria classifications whose transmission comes from outside the region (Ministry of Health, 2014). The high factor of malaria cases is the mobility of the higher population, environmental changes resulting in the widespread land of Anopheles mosquitoes, climate change, community behaviour, and limited access to health services (Decree of the Minister 
of Health of the Republic, 2009).

The city of Trenggalek has conducted an import malaria control program i.e. the discovery and treatment of imported malaria. The discovery of this malaria uses ACD (Active Case Detection) and PCD (Passive Case Detection). ACD's invention was initiated by information from the village device and then the village of Malaria interpreter (JMD) will find the suspect to be taken by his blood preparations.

For the positive malaria sufferers will be given the drug radically using Artemisinin-based Combination Therapy (ACT). Although Pandean Puskesmas has been conducting the discovery and treatment of malaria imports, cases of import malaria are still high.

Human resources are a very important factor in the organization of the company and a government agency. Availability of qualified human resources become the main wealth in an institution, because without the availability of qualified human resources, the activity of an institution will not be carried out properly. The active role of an employee is indispensable in setting plans, systems, processes and objectives to be achieved. Similarly, the role of officers in the Import Malaria control program. The role of officers in the discovery and treatment of malaria import in Pandean Puskesmas is a matter of concern. The purpose of this research is to analyse the role of officers in the implementation of the Import malaria control program, including the availability of human resources, knowledge, training and the understanding of the auth.

\section{METHODS}

\section{This}

research is descriptivebecause it is observed directly without giving the treatment of objects. Research is conducted with observation, collecting, retrieving data and interviewing respondents without intervention affecting the respondents of research. Respondents in this research were officers responsible for the import malaria control program in Pandean Puskesmas. The number of respondents in this study was 8 people, 1 management of malaria Program of Pandean Puskesmas, 2 microscopic, and 5 JMD in Pandean health centers. The subject has criteria i.e. being in the working area of Pandean Puskesmas, engaged in the discovery and treatment of malaria cases imported and willing to be research responders. The research took place in April 2017-January 2018. The role of officers examined in this study is concerned with the availability of human resources, human resources knowledge, malaria training and the understanding of the auth.

The availability of human resources, knowledge, training and auth comprehension of import malaria is measured by questionnaires, where the answers of each variable are given scores and are categorized. In the HR availability variable, the answer is measured with a value, 3 if adequate, 2 if adequate and 1 if insufficient. There are 3 categories in this variable, such as either (with a score of $>$ ), enough (> 5-8) and less (3-5). Knowledge is assessed related to the definition of malaria, malaria parasitic types, causal factors, place of mosquito-breeding, malaria symptoms, prevention, and treatment of malaria. In the HR knowledge variable, the measurement results are divided into three outcomes, i.e. good (Score $>13.4)$, enough (score $>10.7-13.4$ ) and less (score 8-10.7) where if the correct answer get a score 2 and the answer incorrectly score 1 . In the malaria training variable, it is measured by the question of the A-and- In the variables understanding the respondent's auth, on the given question, if properly given a score of 2 and when incorrectly given a score of 1 , then grouped in the category well, enough and less. The methods used in this study have obtained information on the review of the FKM ethics No: 20-KEPK. 


\section{RESULT}

Based on the results, the most age of respondents was 28-37 years. The most genders are males, the most personnel status is the non-permanent officer or PTT, the most recent education is SMA-equal and D3, with the most working hours of 4 to 5 years as shown in Table 1 .

At the availability of the Malaria program officers depicted in Table 2, the entire malaria program officers have a perception of the availability of program managers, microscopic and adequate JMD. Similarly, the level of knowledge of malaria program officers. In the respondent's statement on malaria knowledge, $100 \%$ of respondents had good knowledge.

Table 1. Distribution of Malaria control Program officers of Pandean Health

\begin{tabular}{lcc}
\hline \multirow{2}{*}{ Characteristics } & \multicolumn{2}{c}{ Total } \\
\cline { 2 - 3 } & $\mathrm{n}$ & $\%$ \\
\hline Age & 2 & 25 \\
$18-27$ & 5 & 62,5 \\
$28-37$ & - & - \\
$38-47$ & 1 & 12,5 \\
$48-57$ & & \\
\hline Gender & 1 & 12,5 \\
Female & 7 & 87,5 \\
Male & & \\
\hline Employee Status & 3 & 37,5 \\
PNS & 5 & 62,5 \\
PTT & & \\
\hline Last Education & 3 & 37,5 \\
SMA/Sederajat & 3 & 37,5 \\
D3 & 1 & 12,5 \\
S1 & 1 & 12,5 \\
S2 & & \\
\hline Working time & 2 & 25 \\
1-3 year & 4 & 50 \\
4-5 year & 1 & 12,5 \\
7-9 year & 1 & 12,5 \\
>10 year & & \\
\hline
\end{tabular}

Table 2. Assessment result of availability, knowledge, participation and auth comprehension.

\begin{tabular}{lcc}
\hline \multirow{2}{*}{ Variable } & \multicolumn{2}{c}{ Total } \\
\cline { 2 - 3 } & $\mathrm{n}$ & $\%$ \\
\hline Availability of & & \\
malaria officers & & \\
Good & 8 & 100 \\
Enough & 0 & 0 \\
Less & 0 & 0 \\
\hline Malaria Officer & & \\
Knowledge & & \\
Good & 8 & 100 \\
Enough & 0 & 0 \\
Less & 0 & 0 \\
\hline Malaria Officer & & \\
Training & & \\
participation & & \\
Good & 0 & 0 \\
Enough & 6 & 75 \\
Less & 2 & 25 \\
\hline Auth & & \\
Understanding & 7 & 87,5 \\
Good & 1 & 12,5 \\
Enough & 0 & 0 \\
Less & & \\
\hline
\end{tabular}

The Malaria Program officers have their own basic duties and functions. Table 3 shows the main task and function of the Malaria Program manager and it can be noted that the Malaria Program manager Pandean Puskesmas has done all of its. While on the suitability of microscopic tupoction depicted in Table 4, it is shown that microscopic officers Pandean Puskesmas has done all of his, and on the suitability of the JMD jobdesk described in Table 5 shows the majority of JMD Pandean Puskesmas has done all his. 
Table 3. Distribution of the execution of Malaria Program managers

\begin{tabular}{|c|c|c|c|c|}
\hline \multirow[t]{2}{*}{ Auth } & \multicolumn{2}{|c|}{ Do } & \multicolumn{2}{|c|}{$\begin{array}{l}\text { Not } \\
\text { Doing }\end{array}$} \\
\hline & $\mathbf{n}$ & $\%$ & n & $\%$ \\
\hline $\begin{array}{l}\text { Conducting } \\
\text { inventions and } \\
\text { treatment of } \\
\text { sufferers }\end{array}$ & 1 & $\begin{array}{l}10 \\
0\end{array}$ & 0 & 0 \\
\hline $\begin{array}{l}\text { Creating a } \\
\text { stratification Map }\end{array}$ & 1 & $\begin{array}{l}10 \\
0 \\
\end{array}$ & 0 & 0 \\
\hline $\begin{array}{l}\text { Conduct health } \\
\text { Promotion }\end{array}$ & 1 & $\begin{array}{l}10 \\
0\end{array}$ & 0 & 0 \\
\hline Data analysis & 1 & $\begin{array}{l}10 \\
0 \\
\end{array}$ & 0 & 0 \\
\hline $\begin{array}{l}\text { Implementing } \\
\text { Surveys and } \\
\text { reporting }\end{array}$ & 1 & $\begin{array}{l}10 \\
0\end{array}$ & 0 & 0 \\
\hline $\begin{array}{l}\text { Conducting } \\
\text { training for } \\
\text { spraying personnel, } \\
\text { JMD, BIDES, and } \\
\text { cadres }\end{array}$ & 1 & $\begin{array}{l}10 \\
0\end{array}$ & 0 & 0 \\
\hline $\begin{array}{l}\text { Carrying out } \\
\text { logistic materials } \\
\text { storage }\end{array}$ & 1 & $\begin{array}{l}10 \\
0\end{array}$ & 0 & 0 \\
\hline
\end{tabular}

Tabel 4. Distribution of microscopic main task and function

\begin{tabular}{lllll}
\hline \multicolumn{1}{c}{ Auth } & Do & \multicolumn{3}{c}{$\begin{array}{l}\text { Not } \\
\text { Doing }\end{array}$} \\
\cline { 2 - 5 } & n & \% & n & \% \\
\hline $\begin{array}{l}\text { Create and color } \\
\text { blood } \\
\text { preparations }\end{array}$ & 2 & 100 & 0 & 0 \\
\hline $\begin{array}{l}\text { Examining } \\
\text { Blood }\end{array}$ & 2 & 100 & 0 & 0 \\
Preparations & & & & \\
\hline $\begin{array}{l}\text { Maintain good } \\
\text { laboratory } \\
\text { materials and } \\
\text { tools }\end{array}$ & 2 & 100 & 0 & 0 \\
\hline $\begin{array}{l}\text { Create a report } \\
\text { Pols }\end{array}$ & 2 & 100 & 0 & 0 \\
\hline
\end{tabular}

Table 5. Distribution of JMD main task and function implementation

\begin{tabular}{|c|c|c|c|c|}
\hline \multirow[t]{2}{*}{ Auth } & \multicolumn{2}{|c|}{ Do } & \multicolumn{2}{|c|}{$\begin{array}{l}\text { Not } \\
\text { Doing }\end{array}$} \\
\hline & $\mathbf{n}$ & $\%$ & $\mathrm{n}$ & $\%$ \\
\hline $\begin{array}{l}\text { Visit every Home } \\
\text { (resident) as per } \\
\text { the prescribed } \\
\text { schedule of JMD } \\
\text { heads }\end{array}$ & 4 & 80 & 1 & 20 \\
\hline $\begin{array}{l}\text { Make a good } \\
\text { blood dosage } \\
\text { (meet the } \\
\text { requirements) of } \\
\text { all fever sufferers }\end{array}$ & 5 & 100 & 0 & 0 \\
\hline $\begin{array}{l}\text { Send blood } \\
\text { preparations } \\
\text { immediately to the } \\
\text { JMD head }\end{array}$ & 4 & 80 & 1 & 20 \\
\hline $\begin{array}{l}\text { Responsible for } \\
\text { all tools, materials } \\
\text { and medicines } \\
\text { provided by } \\
\text { Puskesmas }\end{array}$ & 5 & 100 & 0 & 0 \\
\hline $\begin{array}{l}\text { Generate reports } \\
\text { to JMD heads }\end{array}$ & 5 & 100 & 0 & 0 \\
\hline
\end{tabular}

On the conformity of JMD (village of Malaria), the average has done a good job, although there are still one or two people who have not yet carried out some of the main task and function.

\section{DISCUSSION}

In the implementation of a program, one of the important indicators is human resources. Adequate availability of human resources will be influential in the success of a program. If the availability of human resources inadequate can result in less optimal implementation of a job. At Pandean Puskesmas, resources on malaria prevention programmes are at a productive age. Productive age is age when a person is still able to work and produce something, according to the Family Planning Coordinating Board (BKKBN) productive age is at the age of 15-59 years. 
Earning is a creative act that can result in something that is reflected with the action of hard work, intelligent work, being selfreliant does not overlook spirituality and have a living view and forward-looking insight. (Pitoyo, 2013).

According to the Malaria Management manual (Ministry of Health, 2014) mentions the standards of employment in malaria programs are divided into three areas, namely $\mathrm{HCI}$, MCI, and LCI. The proposed standards in this code are the minimum needs of the manpower in a program in order to implement the program effectively and efficiently.

Pandean health centers include the LCI area so that the standards in the malaria program for Puskesmas/UPT consist of 1 person program manager, microscopic 1 person, and cadres amounting to 2 people/village. The results of the study showed a program of malaria in Pandean Puskesmas consists of 1 person program coordinator, microscopic 2 persons, and Kader/JMD amounting to 5 persons but Pandean Puskesmas has no power of KJMD (head of the Malaria Village). This shows that the program of malaria in Pandean Puskesmas is good because it has fulfilled the minimum standards of the Malaria Program, which is required by Dirjen PP and PL Ministry of Health RI, although it does not have the power of KJMD (Ministry of Health, 2014)

There are 5 villages that is a working area of Pandean Puskesmas, so in the division of his work 1 Kader holds 1 village area. Consideration in recruitment of cadres is seen in the geographical framework of Pandean Puskesmas whose territory is $100 \%$ is mountainous territory. Coordinator P2M Puskesmas Pandean explained the availability of JMD that amounted to 5 people with the Division 1 JMD Holding 1 Village area has been adequate to implement the Import malaria control program in Pandean Puskesmas area. The JMD is recruited also to be adjusted to its residence, if JMD served in the area of Salamwates village means JMD is also derived from Salamwates village. This is in accordance with the Code of Malaria Management (Ministry of Health, 2014) on the conditions of recruitment of employment, namely one of them consider the geographical condition factor of the region, social and cultural. Therefore, it is very important to develop human resource planning and the necessary appointment of KJMD because with the presence of JMD heads, it isexpected to coordinate the implementation of malaria control activities in the field in particular to coordinate JMD and Then KJMD gave a responsibility to P2PL Puskesmas Pandean.

HR planning is the process of how to syncronize the current and future workforce needs for an organization. The availability of human resources in the implementation of healthcare plays an important role, this is because in the management system in the Human Resources Service also contributes to both the input subsystem and process subsystem (Mujiati, 2016).

A person's knowledge is a preliminary factor in determining the person's attitude or behaviour in the works. A good level of knowledge of a work will make a person master the field of work (Sumardilan, 2014). The results showed the level of knowledge of malaria program officers in Pandean Puskesmas regarding malaria treatment have been categorized well. This is in accordance with the research of (Prasastin, O.V., 2013) which mentions the level of knowledge of officers who affect the performance of the police officers epidemiology of Malaria disease level health in Kebumen district in 2012. Surveillance officers who have knowledge are having good performance results. Employee knowledge has positive and significant effect on performance. Knowledge is required by health workers in order to specialize in counseling and 
education so that the health information is delivered to the community (Pratama, 2012).

Training on officers is one of the effort to develop the performance of the malaria Program officers to fit the job guidance. The aim of the training is to improve knowledge, skills, and ability as well as to improve, overcome the shortcomings in the implementation of the work to comply with the Program Policy standards (Ministry of Health, 2014)

The results showed malaria training obtained by malaria program officers in Pandean Puskesmas consisting of program managers, microscopic, and JMD are quite insufficient because the Puskesmas's own party never held malaria training. The malaria program officers have received training organized by the district Health Office of Trenggalek and the provincial health office of East Java.

The malaria program officers in Pandean health care have been trained in accordance with the basic duties and functions of each. Malaria Program managers and cadres have gained malaria training more than once in the last 1 year, while microscopic only gained training once in the last 1 year. The type of training that has been acquired is the training of malaria parasitology, training on blood preparation, procedures for making thick drops and logging and reporting systems.

According to the research (Prasastin, O.V., 2013) mentions that there is no relationship between surveillance training officers and epidemiology of malaria diseases with the performance of surveillance officers epidemiology of malaria disease level puskesmas in the district Kebumen in 2012. While other research conducted by (Wicaksono, 2016) mentions that the training could significantly affect the employee's morale according to the training objectives, namely to develop knowledge, attitudes, work skills and Moral workers or officers in their efforts to improve work power or productivity resulting in a quality product.
In addition, also the port can be used to close the gap between employees ' work ability with the demands of the work so that it will be achieved a condition mutually beneficial both for the organization and for workers.

Training and work experience have a positive and significant influence on the quality of employees ' work (Nasaruddin Fadillah, 2008). (Lolowang, Mg., Adolfina., Lumintng, 2016) states that training to employees affects the performance of employees in their organizations. These results indicate that human resource training is essential for employee performance enhancement which will also improve the overall organization's performance. Ongoing training, quality and focus on employee work will improve the performance of employees in an organization or company.

The malaria program officers have their own basic duties and functions. The malaria program officers must know their respective main tasks and functions in order to carry out their basic duties and functions. Routine activities always carried out P2 Malaria at Pandean Puskesmas, among others, active or passive suspect, migration surveys, epidemiological investigations of every positive sufferer, follow-up positive sufferers, treatment Prophylaxis to the manpower who want to depart to areas of malaria endemic and group outreach.

Based on the decree of the (Decree of the Minister of Health of the Republic, 2007) concerning the Malaria training guidelines, it is shown that the malaria program officers have the main tasks and functions to be executed. The P2M Coordinator has seven tupoctions i.e. conducting the discovery and treatment of sufferers, creating stratification maps, conducting health promotion, data analysis, carrying out surveys and reporting, organizing training for the power of sprayers, JMD, BIDES and cadres and do the storage of logistics materials.

In this study, the coordinator of 
P2M who served as the management of Malaria program in Pandean Puskesmas has performed the main tasks and functions in accordance with the number in the order of $043 / \mathrm{MENKES/SK/1/2007}$ (Decree of the Minister of Health of the Republic, 2007). The first tupoksi is to do the discovery and treatment of sufferers, in this case the coordinator of P2M Puskesmas Pandean also participated in an active invention alongside JMD and the import malaria treatment that existed in its working area. The P2M Coordinator conducts supervision on JMD, compiling the import malaria findings in its working territories and participating in the treatment of imported malaria sufferers.

The second tupoction is to create a stratification map. In this P2M coordinator Pandean Puskesmas has created a map of the village post malaria and a map of vector breeding but there is no map of Endemisitas or APIS of every village in Pandean Puskesmas's work area. In the third auth of conducting health promotion, the Coordinator of $\mathrm{P} 2 \mathrm{M}$ has been socializing the socialization of mosquito repellent in 2017 as a form of prevention against malaria and dbd, then socialization of infectious diseases to People are more wary of certain disease symptoms and can do prevention.

The fourth tupoction is data analysis. This research aim is to analyse surveillance data as a form of early vigilance system (SKD) to monitor the KLB. Coordinator P2M Puskesmas Pandean also conducts the auth. In the fifth tupoction of conducting surveys and reporting, Coordinator P2M Pandean Puskesmas conducted a migration survey in the form of prevention of the infection of import malaria. The P2M Coordinator also makes reports on the discovery and treatment of import malaria in its working area each month. The sixth tupoction is organizing training for the power of sprayers, JMD, BIDES and cadres. Coordinator P2M Puskesmas Pandean organizes the training only when the KLB occurs in its working area, not routine every month or year. The last auth is to store logistics materials. Coordinator P2M Puskesmas Pandean not only stores logistic materials for malaria programs but drafting proposals for the needs of logistics to the needs of the malaria program to the head of health centers.

Basic tasks and functions of microscopic officers according to the number of (Decree of the Minister of Health of the Republic, 2007) is to make and dye blood preparations, check blood preparations, maintain good laboratory materials and tools and make reports. The results showed that microscopic officers in Pandean Puskesmas have done all the Auth as stated in Kepmenkes No. 043/Menkes/SK/1/2007. The first tupoction is to make and color the blood preparations. Microscopic officers of Pandean health care have conducted the tupoction of each there is a blood dosage of suspect malaria imported from JMD for laboratory diagnosis. In the second tupoction of examining blood preparations, microscopic officers have also examined the blood preparations of every blood-preparation post from JMD. Blood preparation test used in Pandean Puskesmas is a laboratory diagnosis and use of malaria laboratory SOP. This examination is done immediately after obtaining blood from JMD, plus a microscopic availability of 2 people so that the test results may be out less than 1 day.

The third auth is to maintain laboratory materials and tools. Microscopic officers must maintain the laboratory tools and materials, microscopic Puskesmas Pandean has performed the Auth. The last auth is to create a report. Microscopic officers Pandean also has made a monthly laboratory report of the results of the Sarah Preparation examination and reports to the $\mathrm{P} 2 \mathrm{M}$ coordinator in case of a positive increase in malaria in a village as a suspected KLB.

Based on the number (Decree of 
the Minister of Health of the Republic, 2007), the officer JMD has five auth which is visiting each house (resident) according to the schedule specified to JMD, making good blood preparations (fulfilling the requirements) of all sufferers of fever, To send blood preparations immediately to the head of JMD, responsible for all the tools, materials and medicines given by the Puskesmas and make reports to the head of JMD.

In this research, JMD has also carried out its duties and functions in accordance with the guidelines, but because Pandean Puskesmas does not have the head of JMD then there are some JMD tupoction directly related to microscopic and coordinator P2M. The first tupoksi is to visit every home (resident) according to a scheduled schedule of JMD heads. In this case JMD at Pandean Puskesmas has been carrying out suspect malaria visits to homes as per the prescribed schedule to take their blood preparations. Although sometimes the time of suspect malaria visit can be done at any time. This means if there are suspect malaria imports that return to Pandean Puskesmas area at any time, the JMD officers will directly visit the suspect house to take their blood preparations. But the schedule suspect this visit is not made by the head of JMD but is made directly by the $\mathrm{P} 2 \mathrm{M}$ coordinator because Pandean Puskesmas does not have the head JMD. It can be said coordinator P2M Puskesmas Pandean has a double duty that can result in an unoptimal result $\mathrm{P} 2 \mathrm{M}$ as coordinator.

The second tupoction is to make good blood preparations (fulfilling the requirements) of all fevers. The JMD officers at Pandean Health Care department have made eligible blood preparations because JMD has received training in the thick and thin blood preparations by the provincial health office of East Java. In the case of import malaria is not a fever sufferer who is taken by his blood, but all the new inhabitants returning from outside the island are endemic to malaria.

In the third tupoction is to send a blood preparation immediately to the head of JMD. In this case the JMD Puskesmas Pandean send blood preparations that have been taken directly to the microscopic officers Pandean Puskesmas. This is due to the absence of JMD heads in Pandean Puskesmas so that JMD has a double duty. But the JMD Puskesmas Pandean is able to run all of his/her and optimally, and they do not have any objections in carrying out their duties.

The fourth tupoction is responsible for all the tools, materials and medicines given by the puskesmas. JMD Puskesmas Pandean has performed this auth well. This JMD officer in doing the job field always carries the logistics needs as they need every time down the field so that its function is well fulfilled. While the last auth is to make a report to the head of JMD. In this case the JMD Puskesmas Pandean has made a report on the suspect and treatment findings that have been done and submitted directly to the coordinator P2M Pandean Puskesmas. Reports made by JMD the weekly and monthly reports and then submitted to the Coordinator P2M can be said JMD in Pandean Puskesmas are directly under the responsibility of the Coordinator P2M.

\section{CONCLUSION}

The role of officers in the Import Malaria control program in Pandean Puskesmas is categorized as well, evidenced by the affordwillingness of the already good officers, knowledge has also been good, participation in the training of malaria is sufficient, and understanding Good auth. Malaria officers in the Pandean Puskesmas have carried out all the basic tasks and functions in accordance with the number of the Decree 043/MENKES/SK/1/2007. But they still need to do some improvement in some aspects, such as Pandean Puskesmas need to recruit the power of JMD heads to help 
implement malaria control imports so that the basic tasks and functions of the JMD heads are not obligated by JMD or the management of malaria programs, so that the performance of JMD and program managers can be maximized and the implementation of the Import malaria control program can run more optimally. The district health Office of Trenggalek and the provincial health office of East Java need to increase knowledge and understanding of the Tupoxy on Malaria program officers through training and development activities and Ensure that all officers of the Puskesmas Malaria program follow.

\section{REFERENCE}

Ministry of Health, 2011. Epidemiologi Malaria di Indonesia, Buletin Jendela Data dan Informasi Kesehatan Edisi I.

Ministry of Health, 2010. Laporan Hasil Riset Kesehatan Dasar Indonesia tahun 2010. Jakarta: Badan Penelitian dan Pengembangan Kesehatan

Ministry of Health, 2011. Buletin Malaria; Buletin Jendela Data dan Informasi Kesehatan. Volume 1, Triwulan i 2011.

Ministry of Health, 2014. Profil Kesehatan Indonesia tahun 2014. Jakarta: Ministry of Health RI

Ministry of Health, 2016. Info Datin Malaria. Jakarta: Pusat Data dan Informasi.

Decree of the Minister of Health of the Republic of Indonesia Number 043/MENKES/SK/2007

concerning Malaria Training Guidelines. Jakarta: Ministry of Health RI.

Lolowang, Mg., Adolfina., Lumintng, G., 2016. Pengaruh Pelatihan dan Pengembangan Sumber Daya Manusia Terhadap Kinerja Karyawan pada PT. Berlian
Kharisma Pasifik Manado.

Mujiati, Y.Y., 2016. Ketersediaan Sumber Daya Manusia Kesehatan pada Fasilitas Kesehatan Tingkat Petama dalam Era Jaminan Kesehatan Nasional di Delapan KabupatenKota di Indonesia. Media Litbangkes, 26(4), pp.201-210. https://doi.org/10.22435/mpk.v26i4.48 27.201-210

Nasaruddin Fadillah, 2008. Pengaruh Pendidikan, Pelatihan, dan Pengalaman Kerja Terhadap Kualitas Penyajian Informasi Akuntansi pada PT. Bank Negara Indonesia Tbk. (Studi pada Kantor Cabang BNI di Provinsi Sulawesi Selatan). Jurnal Ichsan Gorontalo, 3(1).

Pitoyo, A., 2013. Menjadi Produktif di Usia Produktif. Direktorat Kerja sama Pendidikan Kependudukan BKKBN, Jakarta.

Prasastin, O.V., 2013. Faktor-Faktor yang Berhubungan Dengan Kinerja Petugas Surveilans Epidemiologi Penyakit Malaria Tingkat Puskesmas di Kebumen Tahun 2012. Unnes Journal of Public Health, 2(4).

Pratama, T.., 2012. Peran Tenaga Kesehatan dalam Membangun Masyarakat Hidup Bersih.

WHO, 2016. World Malaria Report 2016. Switzerland.

Wicaksono, Y., 2016. Pengaruh PelatihanDan Pengembangan Sumber Daya Manusia Dalam Rangka Meningkatkan Semangat Kerja Dan Kinerja Karyawan. Jurnal Bisnis dan Manajemen, 3(1). 